being the case with most of the Riviera torrents. For instance, the channels of the streams near Menton, Vintimiglia, and elsewhere, are far out of all proportion to the work they bave to do. Take the case of the principal stream at Menton. At a distance of less than two miles from the sea where its bed is formed of rock, it bas only a breadth of a few yards, and has no high flood-marks indicating that there is ever a great depth of water. If the stream is followed downwards from this point for less than a mile, the bed is found to open out to a breadth of from sixty to seventy yards. Between these points there are no tributary streams adding their waters to account for this increase. These large river-beds are caused by the nature of the country which these rivers drain. The country is very mountainous, the hill slopes are rocky and steep, large areas have no covering of soil, and what soil there is does not retain the water weil. The result of this is, that when rain falls the water rapidly finds its way to the streams, and the same amount of rainfall is discharged by these streams in a few hours as is discharged in weeks by an English river draining the same area. This accounts for these torrents rising so "high" and falling so "low." It also accounts for them "rising" and "falling" rapidly.

But further, the great and unnecessary breadth of these torrentbeds where they approach the sea seems to be produced somewhat in the following way:-The valleys through which these streams flow descend rapidly from the mountains, but as they approach the sea their slope becomes much slower; the result of this is, that the gravel brought down by the river from its higher and more rapid reaches, is here deposited, on account of the water losing its velocity, and the bottom of the valley becomes filled with a bed of gravel, thruugh which the stream winds sometimes in one part, sometimes in another. A very small cause being sufficient to make the stream "cut" into the gravel and alter the position of its bed, and cause it to flow in different parts of the channel at different times, but it almost never covers at one time the whole breadth of it.

That the bed of the principal stream at Menton is unnecessarily large, is evident from the fact that now, on account of the increased value of land, they are building a retaining-wall near the centre of the stream, and filling up about one-half of the river-bed for the purpose of cultivation.

Rivers similar to those of the Riviera are common to all moun. tainous countries, Britain not excepted. There is at least one salmon river in Scotland, which during the dry season may be walked across withont wetting the soles of one's boots, all the water finding a passage among the gravel. Yet in Autumn, when it has tallen to "fishing condition," it is a stres m of about thirty yards broad, and an average depth of about two feet on the fords. This river is also subject to great floou', which "come down" rapidly, and "fall " rapidly. It also has gravel deposits similar to those of the Riviera torrents, but in this case they are covered with soil and cultivated, and it is with the greatest difficulty and at great expense that the river is prevented from widening its channel to the proportions of those of the Riviera torrents.

Pellagio, Lago di Como, Italy

\section{Method of Distributing Astronomical Predictions}

I BEG leave to observe that the very useful method of dis. tributing astronomical predictions over a given geographical area alluded to in NATURE, vol. xiii., page 71, and ascribed there to Mr. W. S. B. Woolhouse, was already proposed by my father, J. J. von Littrow, in his treatise, "Darstellung der Sonnenfinsterniss vom 7 September, 1820 , "Pest, 1820 , as well as in the Berliner Astronomisches fahrbuch, for $182 \mathrm{I}$, page $\mathrm{I} 16$, and 1822, page 14.5; subsequently in his "Theoretische und practische Astrononie," Wien, 1821, part ii., page 280 ; and last in his "Vorlesungen uiber Astronomie," Wien, 1830, part i., page 306. Since then numerous applications have been made thereof. My father expressed the well-founded desire that in the astronomical almanacs formulæ might be given similar to that communicated in NATURE.

Vienna, June I

\section{Acoustical Phenomena}

IN connection with Doppler's disputed theory of the colours of stars, the illustration usually employed to assist the mind in forming a conception of the hypothesis is that of the whistle of a passing locomotive. The note of the whistle, which, as it approaches, seems shriller than its normal pitch, owing to the greater number of vibrations impinging upon the ear in the unit of time, falls half a tone more or less, as the engine passes and recedes. To unmusical ears the difference in the note is a very doubtful fact, only to be taken on hearsay. There is, however, another fact of kindred nature to which attention has not, I believe, been generally drawn. Almost all railway engines, and especially those drawing heavy goods' trains, have, owing to the manner in which the valve-gearing is set, the property of producing the well-known staccato puffs of steam, audible to the ear as well as evident to the eye. Anyone who will listen to these puffs as the train dashes by will be aware of a very distinct and well-marker change in their apparent rapidity of succession at the moment of passing. So distinct is the change that almost invariably the first effect on the mind is the illusory suggestion that the train has suddenly slackened speed. This change is heard best at night, and when the passing train is a heavy one, not running too quickly. It cannot fail to be appreciated even by non-musical ears. As an illustration of a scientific principle it is, perhaps of the greater value, as a popular error seems to exist on the subject of the change of the note of the whistle, to the effect that the lowering in pitch is very gradual during the approach and recession of the engine, an opinion obviously incorrect if the observer be close to the train.

London, June 7

\section{S. P. THOMPSON}

\section{Giant Tortoises}

In Nature, vol. xiv. p. 6o, it is stated that Commander Cookson, of H.M.S. Petrel, is bringing home two live specimens of the giant tortoise of the Galapagos; that if their food lasts, and if they are not killed by the cold off Cape Horn, they will be the first specimens seen alive in this country.

Even should the tortoises survive the two ifs above given, they will not be the first living specimens seen in this country.

A large specia: en brought from the Galapagos Islands by one of the ships of the late S. R. Graves, M.P., lived in good health for nearly ten years in our Dublin Zoological Gardens.

This animal was examined, after death, by Dr. Günther, who states that it is not identical with the Indian species, as supposed by former naturalists. Samuel HaUghton, Secretary Royal Zoological Gardens,

\section{Trinity College, Dublin, June 2}

\section{Photography of the Loan Collection Apparatus}

THE Loan Collection of Scientific Apparatus at South Kensington contains many apparatus, as for instance the first airpump of Otto von Guericke, the first boiler of Papin, the first locomotive, \&c., which for the friends of science will ever be of great historical interest. Therefore I cannot refrain from expressing the wish that opportunity should be given to take photographs of convenient size of some of the most interesting apparatus. I believe many visitors will foel with me greatly gratified if such a more enduring remembrance could be taken home of an exhibition that perhaps for ever will remain unequalled.

The Hague, June 12

L. B.
ABSTRACT REPORT TO "NATURE" ON EXPERIMENTATION ON ANIMAES FOR THE ADVANCE OF PRACTICAL MEDICINE

THE courteous request of the editor of NATURE that I 1 should contribute to his pages an abstract of my experience of the value of experimentation on animals and on the most useful applications of that method of research to the alleviation, directly or indirectly, of animal suffering in all the higher classes of animals is responded to in the subjoined notes.

I have already expressed my views on this subject on two occasions at large public meetings of the Royal Society for the Prevention of Cruelty to Animals, and in 1862 I made a report on the same subject to the indefatigable secretary of that society, Mr. Colam, which report he has recently published, and which on the points it refers to is in harmony with the conclusions of the late Royal Commission. I have not, however, entered into the discussion that for some months past has been in 